\title{
Versatility in Designs of Punjabi Jutti
}

\author{
Gurdeep Kour \\ HOD, Assistant Professor, Department of Fine Arts, Desh Bhagat University, Mandi \\ Gobindgarh, Fatehgarh Sahib, Punjab.Email: gurdeepkaurı21@yahoo.in
}

\begin{abstract}
The use of footwear is as old as civilization. Numerous experimentations through the hands of Indian artisans of various regions, the form of desi jutti or traditional footwear emerged and circulated in numerous designs during ages. Today's transforming approach of arts has been entered in every field of life to revive and modify our traditional handicrafts to justify our present needs and fashions. This paper is an effort to review the origin and glorious past of the handicraft of desi jutti as well new interventions in the handicraft industry, which affected, altered and fluctuated its original form using contemporary designs, materials and modern techniques. This paper is based on review of literature, interview and observation methods. Data is collected through thirty artisans in Ludhiana. Interviews and discussions also have been done with embroiders, boutique workers, sellers as well as experts.
\end{abstract}

Keywords: Historical, change, contemporary, design, materials, machines, ornamentation.

\section{Introduction:}

This study is an attempt to peruse the new intervention of design in the handicraft industry of Punjabi desi jutti which affected, altered and fluctuated its original form using new materials and modern techniques. Artisans trained in traditional designs over generations, are facing new intervention of design originated as the result of industrial modernity, to revive traditional craft experimenting and treating the conventional as well new materials and computer machines. Design intervention is a practice that encompasses conniving fresh products; restyling surviving products, with changes in shape, size, colour, surface manipulation, function and utility; exploring new markets and reviving erstwhile markets, applying outmoded skills to meet new occasions and encounters and the introduction of new resources, new manners, new gears and skills (Kapur and Mittar, 2014, 3- 4)

Before the advent of Mughals in India, leather and natural fiber were used in making footwear for common people while wooden footwear was popular named as kharaon or paduka among ascetics. Jutti or jutee is an Urdu word for a shoe with a closed upper or 'uparla' attached to a sole, was first introduced by the Mughals and was extremely popular amongst the royalty. It was also called Salim Shahis because being made popular by Salim Shah in the early 16th century. Punjabi desi juttis were originally made of pure leather with exquisite embroidery and embellishments. Desi (traditional) Jutti of Punjab manufactured with flat sole has no distinction of right or left foot with curled upturn toe. Over the centuries, its style and designs have evolved greatly. Today, individual artisans manufacture these leather juttis in an extensive range of colors and designs.

The upper part of the traditional footwear or jutti (jutee) of leather or khal was ornamented with golden, silver and tinsel wires embroideries and precious stones in traditional

(C) AesthetixMS 2020. This Open Access article is published under a Creative Commons Attribution Non-Commercial 4.0 International License (http://creativecommons.org/licenses/by-nc/4.0/), which permits non-commercial re-use, distribution, and reproduction in any medium, provided the original work is properly cited. For citation use the DOI. For commercial re-use, please contact editor@chitrolekha.com 
designs on leather, silk and velvet fabrics but now old- new designs and motifs entered in this field experimenting with new materials through the hands of modern designers, embroiders and craftsmen. The upper part of the jutti consists of any textile or leather. The work of embellish the upper part of jutti is distinct process and is done by the embroiders and later, craftsmen attach the decorative upper part with the main body of leather jutti with a glue pasted on it and finally, a beautiful product comes in front of us in various designs.

\section{Methodology:}

This paper is based on review of literature, interview and observation methods. Data is collected through thirty craftsmen, embroiders and boutique workers of Ludhiana. Some data is also collected through the online jutti shops for analyzing materials and designs used in the product. Historical data is also collected through museums. The exploratory method is applied for writing the paper.

\section{Glorious Past of the Traditional Footwear:}

Traditional footwear of leather or khal jutti adequately ornamented with golden-silver threads and precious stones tells the story of its magnificent past. From the Mughals till today, traditional desi jutti is favorite of the royals as well as common both because of its comfort and ethnic look. The work of Zardozi Embroidery was popular for decorating traditional footwear. There are various references in Hindu- Vedic epics about the tradition of gold-silver thread embroidery on fabrics. But the term 'zardoz' or 'zardos' came from Persian vocabulary as 'gold wire is termed zari, a Persian word for gold (Gupta, 1996, 73). Fabrics ornate with gold suggest magnificent lavishness conjuring historic grandeur (Gupta, 1996, 33). Zari or zardosi embroidery is the traditional embroidery and was the most popular among royals from the very beginning. The work of zari embroidery with golden-silver wires touched its altitude during Sultanate period in Delhi (Gupta, 1996, 37). During Muhammad Tughlak, 'zardozi' became the court dress and the work of zardozi extended in Gujrat, Rajasthan and Bengal with the change of political centers (Gupta, 1996, 39-40).

Mughal dresses along with footwear (fig. 1) were also made of golden- silver zardozi embroideries as there are various Mughal miniatures (British Museum, nos. 1949,1210,0.10 and 1974,0617,0.10.10 and 1920,0917,0.13.6. Also see Cleveland Museum, nos. 1917.1066, 2013.293, 2013.323, 2013.324 and 2013.313. Also see Asian art museum, no. 1998.94), in which examples of Mughal zari embroidered footwear also depicted with various designs and colours. Detailed descriptions are also available in Ain-a- Akbari and Tuzuk-i- Jahangiri about Mughal zardozi centers. Centers of zardozi also changed with Mughal capitals time to time. As influences of Mughal lifestyle were vast in whole India, the work of zardozi extended to other regional centers and became popular in whole India.

During Mughals, Agra, Delhi, Gujarat, Lucknow, Rajasthan and Punjab were the main centers of traditional footwear. The Kafsh was worn by nobles and kings. The Charhvan, with a curling tongue fixed to the toe, the Salim Shahi, decorated in gold, the Khurd Nau, was very lightweight, made of kid leather. Lucknow was the most famous center for the zardosi (fig. 1) done on footwear upper in Mughal times and the art of aughi, embroidery on leather and velvet footwear, was also very popular. Since the 17th century onwards, through the reign of Emperor Jahangir, mojiris with inverted toes were acquainted (Neubauer, 2003). Currently, Kolhapuri chappal of Maharashtra, Mojri of Rajasthan along with Punjabi jutti are also very eminent in the 
form of customary racial footwear. Innumerable treatments were widespread in zardozi work (Chattopadhyaya, 1964, 10).

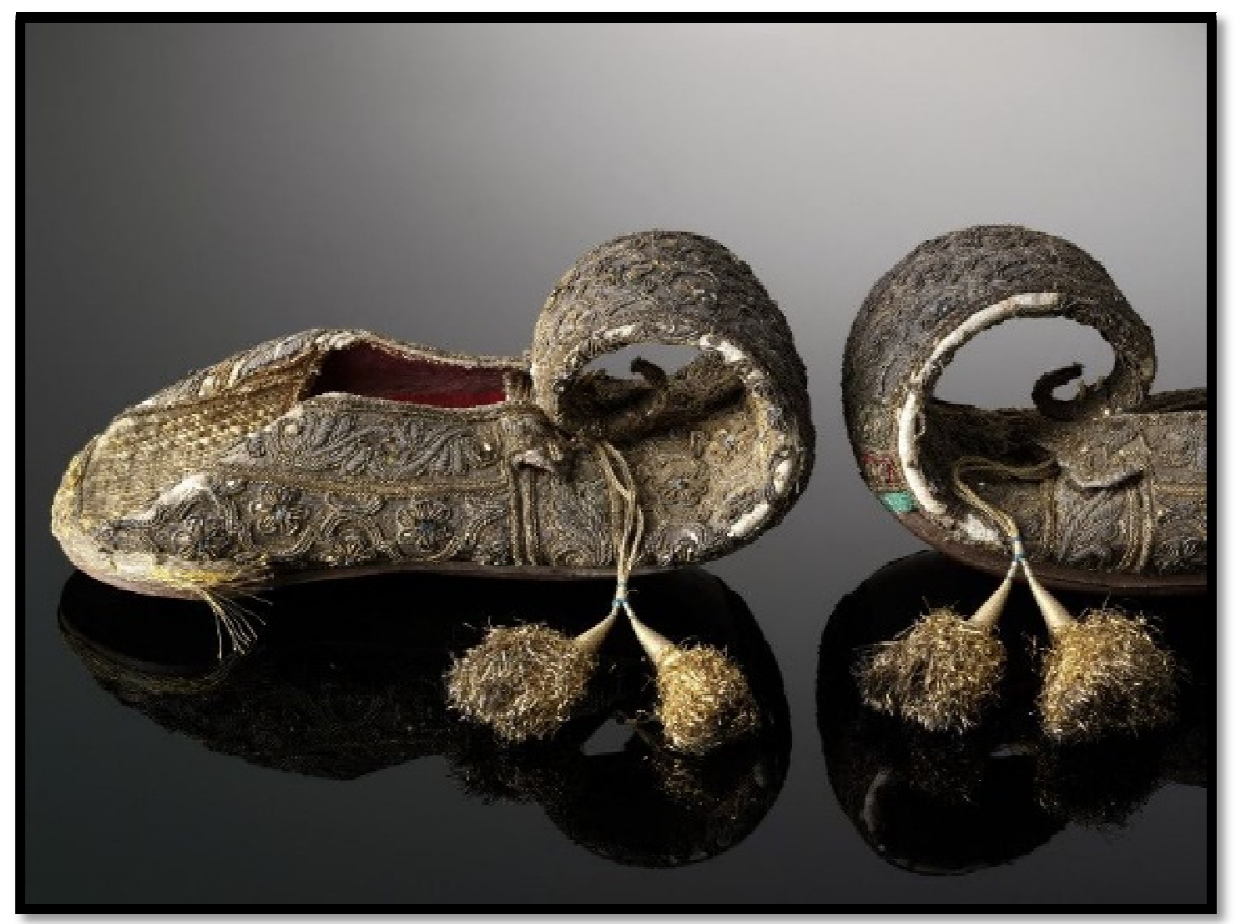

Figure 1: Zardosi footwear, Source: Victoria and Albert Museum, Museum no. 0515(IS), Lucknow, 1855.

\section{Punjabi Jutti:}

The major centers of this traditional craft in Punjab are Kasur, Narowal, Chakwal now in Pakistan, Muktsar, Patiala, Amritsar, Malerkotla and Pathankot etc. There are numerous varieties of desi jutti produced in Punjab (Metropolitan Museum, Accession nos. C.I.40.139.14a, b and C.I.66.55.1a, b and C.I.48.69.11a, b. Also see Asian museum Object nos. 1998.63.13 and 1998.63.12 and 1998.63.5 and 1998.63.19) at various centers (fig. 2) and every center has its own distinctness of design like, the city Kasur is famous for its traditional embroidery (Singh, 2011, 61), Narowal; for ornamentation (Singh, 2011, 62), Chakwal-Pothohari; or chakwali jutti for high heel and long tip and back side of leather is applied in it (Singh, 2011, 62), Muktsari jutti; for tilla, zari, phulkari, and Patiala; for its Patialashahi with heavy embroidery or kadavi (embroidery) and bright colors. Mundi or desi jutti is with no particular distinctness of right-left, Ghoni jutti (Singh, 2011, 67), without nob, Nokdar jutti (Singh, 2011, 67), is with nob, Khosa or khussa jutti is with broad and long nob, Lukki or lak marvi jutti is with broad front and end and middle remains narrow.

The basic material used for jutti is leather of different types. Dhodi jutti (Singh, 2011, 66) is made of hard leather like buffalo, cow, camel, Kuram jutti (Singh, 2011, 66) of black leather, Nari jutti (Singh, 2011, 66) of soft leather of goat, Dukhli jutti (Singh, 2011, 66) is made of double leather (used inside-outside of jutti). The raw materials used for making jutti have under gone changes. For the decoration of upper part, silk threads of different colours, metal threads and wires of gold, silver, copper as well as precious stones and pearls were used to decorate the jutti of royals. Thick cotton thread of white colour is used for stitching jutti. The main body of jutti always remains of leather, but now it depends on availability of leather, and some substitutes of leather are also 
available in market. Upper part of jutti is used to decorate, which gives it distinctness and variety to fulfill the demands of various classes.

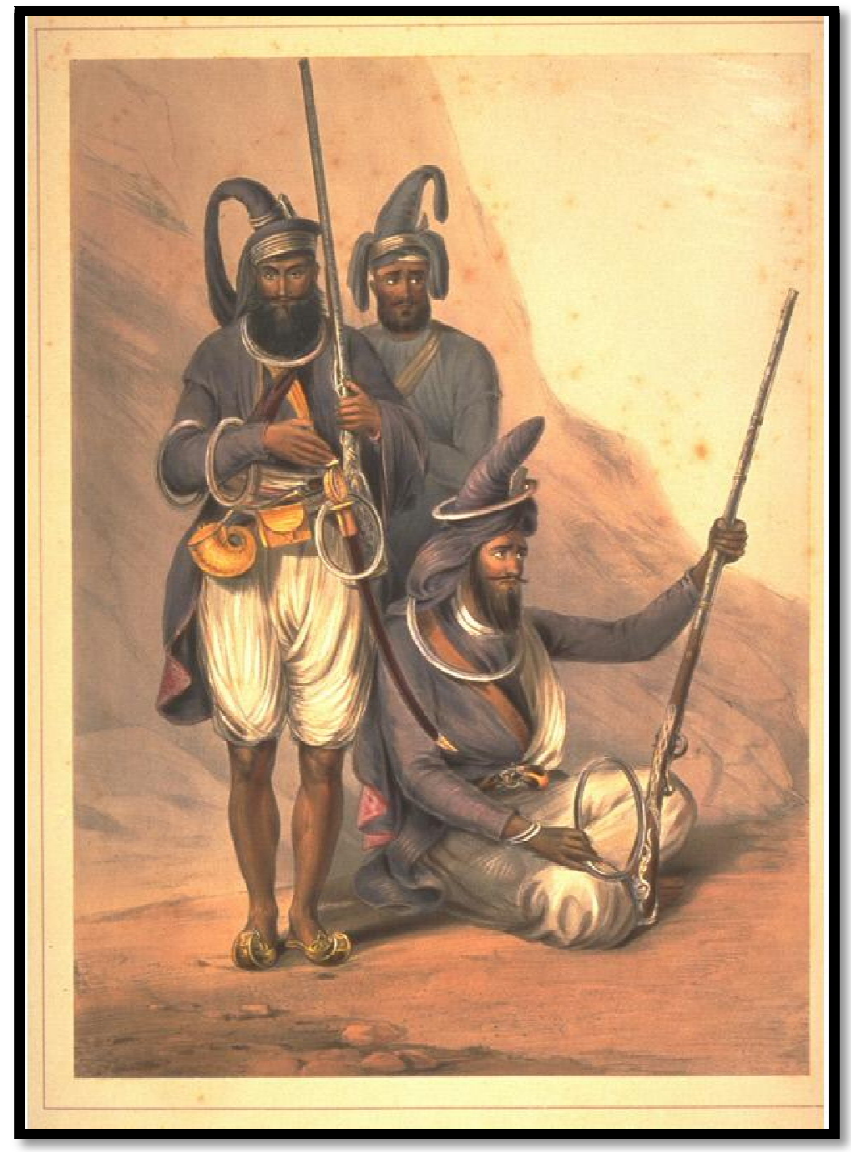

Figure 2: Traditional Punjabi Jutti with long nob, source: Asian Art Museum, Object ID: 1998.63.5

\section{New Interventions in the Craft of Desi Jutti:}

\subsection{Changes in Basic Materials:}

Previously, first buffalo, cow, sheep, calf and sambher hides were applied, but at the present as leather is infrequent commodity in Patiala, raxin, velvet Japani, canvas, hardboard, sheet sole (rubber), leather board, which are imported from Delhi are chiefly used. Different raxin ranges are available - Taiwan, Aero plane pillow Drammer, Milar, Marble, Crepe, Soft foam, Ice nappa, Leather nappa, Nappa, Capsule foam, Wrinkles and Gumeri, foam etc., out of which Taiwan is of good quality and most commonly used. The raxin jutti has reduced the gap between rich and poor and is finished in such a way that it looks and smells like leather (Kaur and Joseph, 2010, 172). Denim fabric, canvas, plastic, rubber, Banarasi silk, raxin and velvet are the new materials used for making the body of Punjabi jutti replacing the leather due to unavailability and the art of currying leather was hard manual labor, needing great skill and a range of special hand tools. Easily available fabrics invite the designers to innovate their imaginations on the upper part of jutti to compete modern footwear on the global level. Denim is a woven material and produce in different styles. Compared with natural leather, synthetic and artificial leather, denim material as fabric is precise in beautification. Diverse necessities and directives are for denim from those for 
leather during manufacturing (Zhai, 2011, 1643). Denim is an artificial material and knitted by warp and weft (Zhai, 2011, 1646). Frequent material or adornments can be harmonized to the denim shoe upper (Zhai, 2011, 1645). Brocade, velvet, mashru, cotton and canvas are the fabrics which can be easily dye, decorate, paint and composite material. Traditional motifs, and colours has been altered in modern motifs and colours under the influence of abstraction. Handmade and machine made embroideries on decorative materials like silk and brocade are also in fashion to match modern dresses.

\subsection{Embroidery Machines:}

Though, craft is a form of product for the craftsmen and for folks, who command a craft item for ingesting, with a precise ethnic, ceremonial or efficacy context, they prerequisite to be visibly discerned from machine-made produces. The input of handiwork and time endowed in generating a craft, conveys such tenets within it, which a machine-made, bulk created product can never accomplish (Chowdhury, 2012). The use of embroidery machine is a new intervention in the field of this handicraft, which manipulated its basic concepts and methods and materials. Zardozi embroidery with metal threads was popular to decorate juttis but traditional skill hurt by machineries; and big manufacturers and dealers got profit. From the second half of nineteenth century, sewing machines are used to stich fabric. Embroidery machines are big revolution in the field of tailoring and designing. Machine and hand embroidered upper parts of juttis are mostly made in Sanaur village near Patiala. Females are principally involved in hand embroidery in Sanaur, though menfolk are involved in machine embroidering the upper part of juttis. Machine jutti embroidery industry had ongoing around 5-6 years back here (Kaur and Joseph, 2010, 171172)

\subsection{New Materials Emerging Modern Designs:}

Today, 'Design intervention' has been entered in every field of life to modify the products. Traditional artisans are also influenced towards new materials and designs. Instead of golden, silver and silk threads and metal wires for the decoration of upper part, now, new materials are also used to decorate juttis by the jutti embroiders. Ceramic beads, bells, small mirrors, cowry shells, tilla, zari, phulkari and brass nails are popularly used to decorate jutti to merge traditional and contemporary concepts. Traditional and modern embroiders as well as boutiques are also involved in the designing of juttis to fulfill the needs of customers. Costumers' demands also influence the designs and manipulate them. Juttis are also made to match the ceremonial dresses of the consumers.

Today, cheap metal wires are used in this embroidery on different fabrics and leather replacing costly wires. The preparatory process of the wire is not only industrialized, but there is also a radical amendment in the raw materials, which have been substituted from time to time for the gold leaf which was gilded in the silver mould (Gupta, 1996, 73). Today, regional and tribal styles of embroideries and printing in their popular motifs are used to decorate modern juttis (fig. 3) in which tie and dye called bandhani, zardosi, kashidakari, chikankari, phulkari and mirror embroideries are common. Rajasthani embroidery is also used to make decorative footwear (Dhamija, 1964b, 42).

Handmade and machine- made, both type of phulkari or gulkari embroidery inspired by flowers have roots on the land of Punjab. Geometrical forms in same technique is called bagh or square garden. Both, geometrical and floral motifs are popular to embellish juttis. It has infinite number of patterns testifying to the creative ability of the needlewomen, make up of parallel, straight down and slanting stiches. Apiece variability has a distinct label as bagh, and every bagh in turn has a different name like shailmar bagh, Lahori bagh, kakri bagh, mircha bagh, dunya bagh, 
grounded on the different patterns which offers the particular design its appellation. The remarkable fact is that with the skillful manipulation of the darning stitch so miscellaneous ranges of intricate designs are shaped, with an entire effect of floral grandeur (Chattopadhyaya, $1964,6)$.

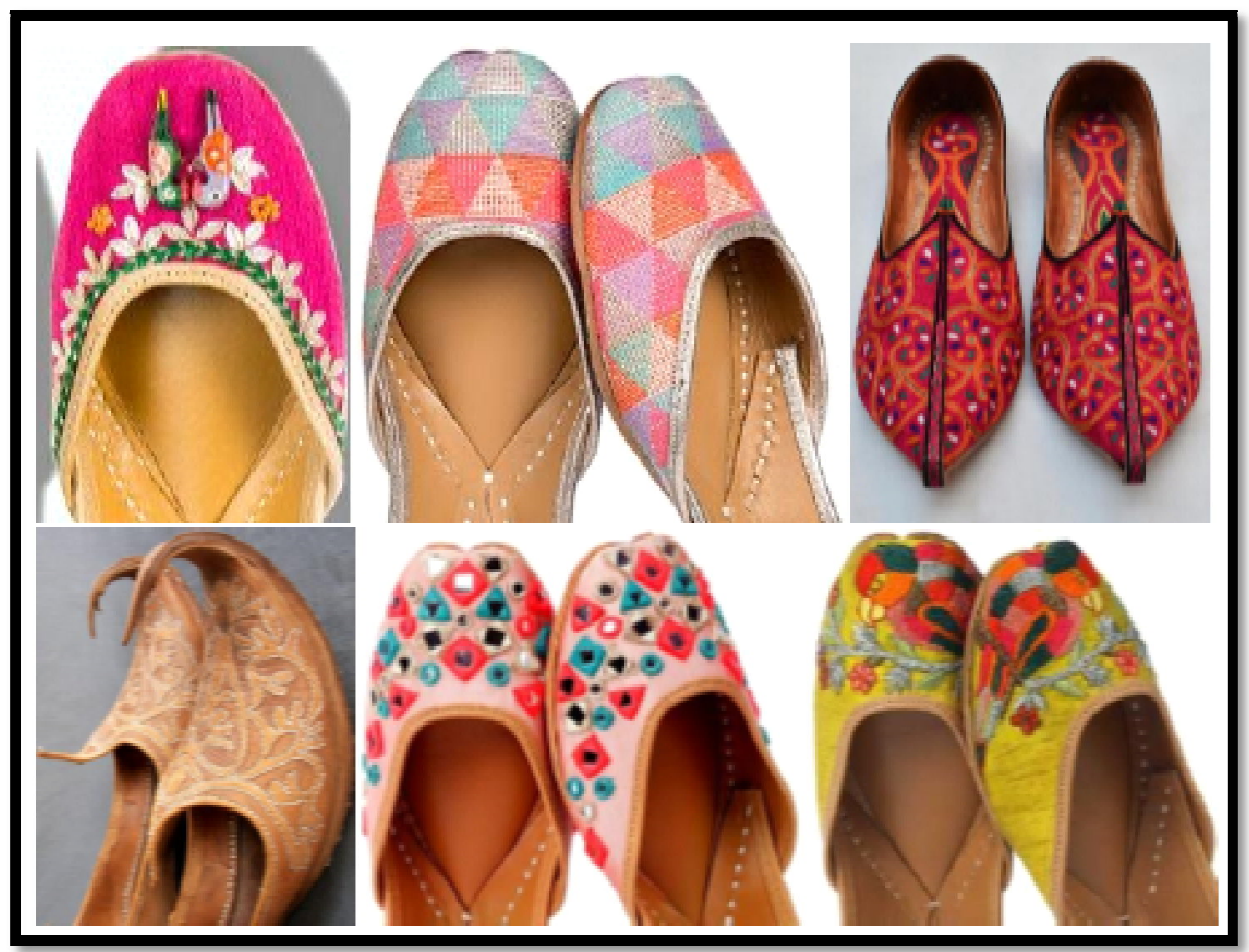

Figure 3: Regional Embroideries and Designs

Kashida or Kashmiri embroidery done with crochet or aari is the traditional embroidery of Kashmir from the Mughal times mainly used to decorate shawls, is also used popularly on juttis. Indo -Persian motifs called buta, Kashmir cone (Irwin, 1955, 130- 135). Kashmiri kashida as well as kashida and sujani of Bihar, Jamdanis of Dacca, kantha of Bengal and embroideries from Manipur, Bihar, Murshidabad are too in fashion for the upper of jutti.

Chikankari of Lucknow; a style of white threaded needlework on light coloured textile exclusively on muslin, is a customary stitching of Dacca and Bengal, brought to Lucknow, Delhi and Rampur during late Mughals (Dhamija, 1964a, 25). Patterns used in embroidery also based on different types of stitches. Now, it is also used to decorate juttis in most common motifs of the creeper / vine with many types of flowers thrown in. Grains of different types and other motifs like the coriander leaf stalk, grass stalk, mango designs, palm leaf motif and animal as well as bird motifs are also common.

Guajarati Embroidery and Mirror Work of Kutch is also popular for juttis. The Cutch embroidery is distinguished for its intricate decorativeness called Kanbi after the cultivator, the Kanbi, and Ahir the cowherd, the derivation of the word being from Sanskrit meaning milkman (Chattopadhyaya, 1964, 6). The Shisha or glass embroidery was originated in the 17th-century in India. Contemporary shisha work almost entirely consists of mass-produced, machine-cut glass shisha with a silvered backing, in varying shapes and sizes. In the dresses of Gujarat, we can easily see shisha or mirror embroidery. Now we can see this mirror work on juttis. The practice of motifs in the embroidery is not restricted to rustic subjects, for one finds them lifted out of spectacle, 
like cheerily tapestried elephants, blinds, fans, twirling peacocks and the ample shaded parrots (Chattopadhyaya, 1964, 6).

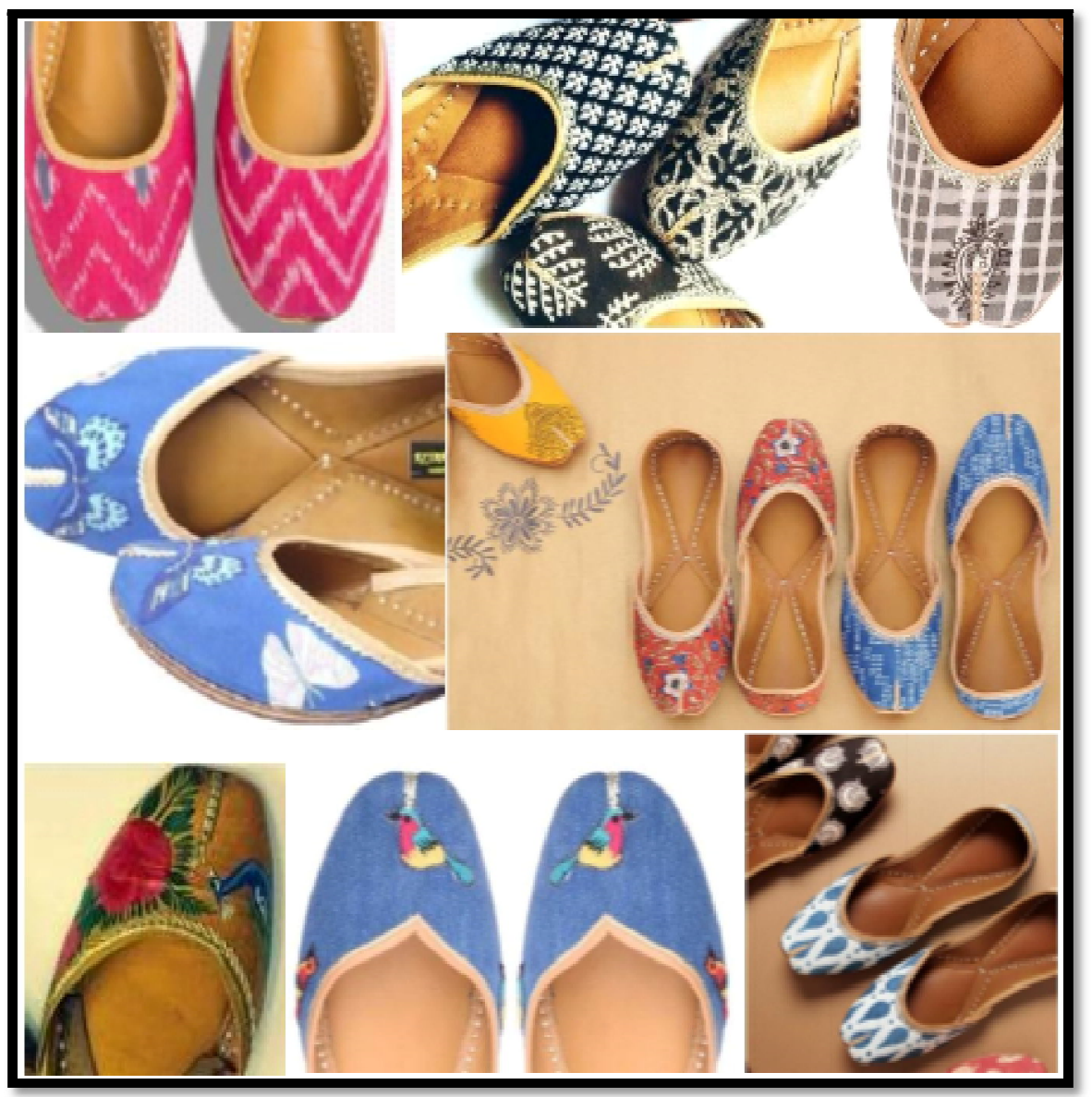

Figure 4: Traditional prints used for footwear

Mirror or Kathiawar embroidery is done by Kathiawar women, with the lavish use of mirrors and bright colours depicting different themes. They are Heer-Bharat, Abhla Bharat, Chain Stitch embroidery of Bhavnagar range, interlacing stitch known as Sindhi, applique work and lastly Moti Bharat bead work (Dhamija, 1964c, 48-49). Because of the popularity of computer embroidery machines, now it is easy to do embroidery on different types of leather through machines in very less time. Along with hand-made embroidery, machine-made emroidery on leather jutti is also in fashion.

The tradition of painting is as old as human being himself. Now, art of painting inspires every product to decorate. Fashion to paint different motifs on juttis is now very popular among young generation. Tradition of dyeing and printing in India also goes back to Indus valley civilization, centered in Barmer, Jaisalmer, Udaipur, Jaipur and Chittorgarh (Dhamija, 1964d, 2224). Bagru and Sanganer are the villages of Rajasthan's historic block printing. Craftsmen use hand carved wooden blocks to stamp designs onto the cloth with natural techniques. It also gives formal look to the traditional footwear and on low prices customers get beautiful and simple juttis (Mishra, 1964, 25). Now, Denim, silk, hemp, cotton etc. are the natural fabrics used for shibori and cellulose fibers such as cotton, hemp, rayon, and linen are used for tie and dye or bandhani. Natural prints of two colours (Jayakar, 1951, 42- 43) are created on the different natural fabrics in 
different popular ways and those fabrics are used on the upper part of jutti to give the traditional footwear a formal appearance. Different flowery and geometrical motifs along with their intermixtures, numerous patterns are created and used to decorate traditional footwear. Paisley motifs or bootah or floral motifs are also very ancient and are used to embellish juttis.

Kalamkari or qalamkari is a type of hand-painted or block-printed cotton textile, produced in Iran and India. Its name originates in the Persian, which is derived from the words qalam (pen) and kari (craftsmanship), meaning drawing with a pen practiced in Andhra Pradesh, particularly in Kalahasti and Machilipatnam, now also popular for Punjabi juttis.

Gujerat was the soul of the cotton printing belt and, from as early as the first century A.D., Gujerat with its anchorage of Barygaza (Broach) on the river Narmada was exporting Indian cotton prints (Jayakar, 1951, 40). The use of wooden blocks in printing the design before the cloth was waxed has been in use in Gujerat from the eighteenth century. The practice of blocks, yet, must be very much older and block making center is Ahmadabad. (Jayakar, 1951, 42) (Fig. 4).

Blend of Indo-western also appear in juttis. It is very easy to paint, print, dye and stitch denim. So it is very popular fabric among embroiders, dyers, painters as well as youngsters to match modern western dresses with traditional footwear. Tassel or Pompoms or Needle Dust made of Waste thread pieces are also used to decorate juttis and other dresses. It also gives a formal look to the traditional footwear. Ghungroos or small bells are attached to give an informal look to the juttis. It gives traditional appearance to modern and altered footwear. The dori made of different fabrics for tie is also in fashion and is used in juttis to match ethnic- modern dresses.

\section{Conclusion:}

Machine made products consuming less time and manpower create much effect and because of less production cost, are popular among common. Globalisation has been capable to link spaces, but has ensued in splitting the bygone from the contemporaneous. Machines, new tools and modern materials and design intervention are connected and influenced each other. Unavailability of traditional materials and rising cost of traditional materials and demands of modern consumers are also interconnected and influence each other. Experimentation in traditional designs and materials also helpful to compete global needs and helpful to maintain importance of traditional craft in innovative way. Now artisans can create unlimited designs through various modern materials. There are numerous varieties of Punjabi jutti in markets. It is a merger of tradition with modernity, but it creates problems to traditional skilled artisans.

\section{References}

Chattopadhyaya, Kamaladevi. (1964). Origin and development of embroidery in our land, Marg, XVII (2), pp. 5- 10.

Chowdhury, R. (2012). An Analytical Study of Impact of Regulation and Audit-societies on Craft Ecology. Kolkata: National Institute of Fashion Technology.

Dhamija, Jasleen. (1964a). Chikankari. Marg, XVII (2), pp. 25- 26.

Dhamija, Jasleen. (1964b). Rajasthan embroidery. Marg, XVII (2), pp. 40- 43.

Dhamija, Jasleen. (1964c). Kathiawar. Marg, XVII (2), pp. 48- 49.

Dhamija, Jasleen. (1964d). Survey of arts and crafts of Rajasthan. Marg, XVIII (1), pp. 21- 24.

Gupta, Charu Smita. (1996). Zarzodi glittering gold embroidery. New Delhi: Abhinav Publications. Print.

Irwin, John. (1955). The Kashmir shawl origin and technique. Marg, VIII (2), pp. 121- 136. 
9 | Versatility in Designs of Punjabi Jutti

Jayakar, Pupul. (1951). Cotton prints of Gujerat \& Kathiawar. Marg, 4 (4), pp. 40- 43.

Kapur, Harita and Mittar, Suruchi. (2014). Design intervention \& craft revival. International Journal of scientific and research publications. 4: 10. 1-5. ISSN 2250- 3153. Online.

Kaur, Prabhjot and Joseph, Ruby. (2010). Dying art of Punjabi jutti in Patiala. Asian journal of Home Science. 5: 1. 170- 175. Online.

Mishra, Lalita. (1964). Sanganer printing, Marg, XVIII (1), pp. 25.

Jutta, Jain-Neubauer. Reviewed by Radhakrishna, Sabita. (Jan 05, 2003). Feet and Footwear in Indian Culture. Published in 'The Hindu'. Online edition of India's National Newspaper

Singh, Gurinderbeer. (2011). Jutti, Sankalp te sabhiyachar. (Gurmukhi). Amritsar: Ravi Sahit Prakashan.

Zhai, Jinging. (2011). The Denim's characteristics as upper material of footwear. Advanced materials research, ISSN: 1662-8985, Vols. 332-334. 1643-1646. Online.

Gurdeep Kour, Assistant Professor, Desh Bhagat University, Fatehgarh Sahib, Punjab. Former Research Scholar of Fine Arts, Lovely Professional University, Phagwara, Punjab, India. Email: gurdeepkaur121@yahoo.in 